\title{
Rearing Male Layer Chickens: A German Perspective
}

\author{
Mona Franziska Giersberg *(i) and Nicole Kemper \\ Institute for Animal Hygiene, Animal Welfare and Farm Animal Behaviour, University of Veterinary Medicine \\ Hannover, 30173 Hanover, Germany; nicole.kemper@tiho-hannover.de \\ * Correspondence: mona.franziska.giersberg@tiho-hannover.de; Tel.: +49-511-856-8963
}

Received: 19 October 2018; Accepted: 6 November 2018; Published: 9 November 2018

\begin{abstract}
The killing of male layer hybrids in the hatcheries, at a day-old, is common practice but it also raises strong socio-ethical concerns. In recent years, three different approaches to avoid this killing have been developed-the in ovo sex determination, the rearing of male layers for meat, and the use of dual-purpose breeds. In Germany, about one million male layers are raised each year in the organic and conventional sector. Regarding animal health and welfare, this concept seems favourable. However, the main challenge, that is, to what extent these animals can be kept in a resource-friendly and ecologically sustainable way, remains yet to be solved. Currently, for a niche, this approach contributes to the diversification of the German market. It serves as an example for reacting to societal concerns immediately, before feasible solutions are available for the entire system of modern poultry production.
\end{abstract}

Keywords: animal welfare; animal ethics; poultry; culling; day-old chickens; sustainability

\section{Introduction}

The genetically-determined antagonism between reproduction and fattening performance in chickens has led to specialised hybrids for egg and meat production. In broiler hybrids, both sexes are used for meat production. However, since male layer chickens are not suitable for economic fattening purposes, they are usually killed by maceration or carbon dioxide, in the hatcheries, at a day-old. Currently, $70-89 \%$ of the German consumers are aware of this practice [1,2], which may be due to increased media reporting, in recent years. The majority (67\%) of the respondents rated the killing of newly-hatched chickens "very problematic" [1]. Along with the socio-ethical concerns, it has been legally discussed whether the killing of male day-old chicks can be justified by "good reason" as defined by Article 1 of the German Animal Welfare Act [3]. The Higher Administrative Court of North Rhine-Westphalia decided, in 2016, that this would still be the case, since rearing these chickens would involve a disproportionate effort [4]. In the following, current developments to avoid the killing of male chickens are reviewed with special focus on the concept of rearing male layer hybrids for meat in scientific projects, and in agricultural practice.

\section{Discussion}

There are three different approaches to avoid the killing of male chickens:

(1) In ovo sex determination: By the means of endocrinological or optical methods, the sex of the chick embryo is determined, at a preferably early phase of incubation [5]. Eggs identified as "male" can thus be separated and further processed. The resulting high-quality proteins could be used, for instance, in the pet food or chemical industry. In 2017, a fully automated technical solution for spectroscopic in ovo sexing was presented in Germany [6]. The system detects the embryo's sex with $98 \%$ accuracy, at the fourth day of incubation. Its application in a commercial hatchery is expected at the end of 2018. 
(2) Keeping dual-purpose breeds: Hens from these lines lay a sufficient number of eggs whilst males show an acceptable fattening performance. The aim is that both sexes gain economic value. Dual-purpose hybrids are offered by leading breeding companies, for instance Lohman Dual (Lohmann Tierzucht). Another option is the use of traditional dual-purpose breeds, such as Les Bleues, or simple crossbreeds of those. However, due to the negative correlation between reproduction and fattening traits, dual-purpose chickens cannot achieve the production performances of specialised hybrids. In addition, neither the commercial nor the traditional dual-purpose chickens are currently available on a large scale, in Germany.

(3) Rearing male layers (also referred to as "laying hen brothers"): This means the "fattening" of the male offspring of modern high-yielding layers. The German organic sector aims at poultry farming which is independent from international breeding companies. The long-term goal is the self-organized breeding and the provision of sufficient numbers of dual-purpose chickens, for the whole organic sector. Since these efforts are in their infancy, the hens which are in the present breeding and selection process, are still valued for their laying performance, and the males are reared without distinct economic value.

In recent years, several scientific projects on the production performance of male layer hybrids [7,8], and on the processing and marketing of the carcasses [9], were carried out. Furthermore, male layers were studied in alternative housing systems, such as mobile houses [10], or in control groups in investigations on the behaviour of dual-purpose breeds [11]. In 2015, about 100,000 male day-old chickens were raised by the organic sector in Germany, per year [12]. This number has increased to about 270,000 reared male layer chickens, in 2018 [13]. In addition, retailers and larger producer groups conducted pilot projects raising about 700,000 male layer hybrids, per year, for the conventional market [14].

Both in scientific projects and in practice, the mortality rates of male layers (1-2\% per batch) are negligible $[10,11]$. Except for vaccinations, veterinary treatment is usually not necessary. Since male layers are kept for a longer period, re-vaccinations have to be considered. Management-related problems, such as pododermatitis, are scarcely observed [11]. Depending on the farm and additional regulations of organic-label programs, male layers are kept in littered single-tier systems with or without access to pasture, or in mobile houses. The barns are usually enriched with perches and straw bales. Since some farmers report aggressive behaviour with the increasing age of the chickens, additional enrichment is recommended (e.g., hay bales, pecking blocks, grass silage, or separate dustbathes). The "fattening period" ranges from 8.5 to 18 weeks, during which the animals are fed standard broiler diets or the farm's own low-nutrient mixtures. With average daily weight gains between 9-13 g (organic) and 18-20 g (conventional), male layers reach targets weights of 1.3 to $1.5 \mathrm{~kg}$. Accordingly, the FCR (feed conversion ratio) varies between 4.0 and 10.0. Carcasses declared unfit for human consumption are rare $[10,15]$.

If the male chickens were raised, $89 \%$ of the German consumers would be willing to pay more for eggs, $52 \%$ of them up to $6 \mathrm{c}$ per egg [2]. Initiatives or individual farms which rear male layer hybrids usually compensate for the economic disadvantages by adding extra charges to the egg prices, since even prices of $10 € / \mathrm{kg}$ rooster meat are often not cost-covering. The eggs are offered under special brands or labels via farmgate sales or retailers. The meat of males is marketed with analogous labelling as whole carcasses or convenience product, such as chicken hotpot. For self-marketing farms, however, the meat sales seem difficult with decreasing media reporting on "chick culling". When meat of male layers is sold by retailers it is-unlike the eggs—usually not labelled but processed for traditional products like fricassee. In collaboration with the local gastronomy, Kaufmann and Andersson [10] investigated if male layers could be marketed as a delicacy with distinct economic value. A tasting carried out in the context of the study was rated positively by the guests. In addition, the meat of male layer hybrids seems to be suitable for the production of cured-cooked products and fermented sausages [9]. 
The major challenge concerning the rearing of male layers is the ecological impact of this concept. The longer fattening and the high feed costs are disadvantageous, in terms of economic and ecological sustainability. Further research is needed if male layers could utilize resources which are largely unused, such as leftovers from the food production. In addition, at farm level, egg and meat production are usually separated. Thus, egg producers do neither have the capacity nor the know-how to raise meat chickens. Therefore, a co-operation bundling the fattening, on specialised farms, is necessary, which may raise concerns regarding transparency. A further challenge is the marketing of the products, which requires special efforts, even in the organic sector. However, in ovo sexing technologies, which do not require any changes in the poultry production, are currently not accepted by the German organic sector [16].

\section{Conclusions}

With regards to animal health and welfare, rearing male layers is largely unproblematic. The main challenge, i.e., to which extent these animals can be kept in a resource-friendly and ecologically sustainable way, remains to be solved. "Fattening" male layer hybrids is clearly not a suitable alternative for the mass or world market. However, for a niche, this approach contributes to the diversification of the market and serves as an example for reacting to societal concerns, immediately, before feasible solutions are available for the entire system of modern poultry production.

Author Contributions: Conceptualization, M.F.G. and N.K.; Writing-Original draft preparation, and review and editing, M.F.G. and N.K.

Funding: This research received no external funding.

Conflicts of Interest: The authors declare no conflict of interest.

\section{References}

1. Busse, M.; Siebert, R. Einstellungen zu ethischen Aspekten in der Geflügelhaltung. In Ökologischen Landbau Weiterdenken-Verantwortung Übernehmen-Vertrauen Stärken, Proceedings of the 14. Wissenschaftstagung Ökologischer Landbau, Freising-Weihenstephan, Germany, 7-10 March 2017; Wolfrum, S., Heuwinkel, H., Reents, H.J., Eds.; Verlag Dr. Köster: Berlin, Germany, 2017. Available online: http:/ /orgprints.org/31888/ (accessed on 9 November 2018).

2. Forsa. Umfrage “Meinungen zu Eintagsküken” im Auftrag der Verbraucherzentrale Nordrhein-Westfalen e.V. Available online: https:/ / www.verbraucherzentrale.nrw/pressemeldungen/presse-nrw / eierproduktionohne-toetung-maenmaennli-kueken-9970 (accessed on 9 November 2018).

3. Beckmann, M. Über den vernünftigen Grund im Sinne von § 1 S. 2 TierSchG bei der Tötung von männlichen Eintagsküken. Nutur Recht 2016, 38, 384-390. [CrossRef]

4. Oberverwaltungsgericht NRW (Higher Administrative Court of North Rhine-Westphalia, Münster, Germany), 20 A 488/15, Decision of 20th May 2016. Available online: http:/ /www.justiz.nrw.de/nrwe/ ovgs /ovg_nrw/j2016/20_A_488_15_Urteil_20160520.html (accessed on 9 November 2018).

5. Krautwald-Junghanns, M.E.; Cramer, K.; Fischer, B.; Förster, A.; Galli, R.; Kremer, F.; Mapesa, E.U.; Meissner, S.; Preisinger, R.; Preusse, G.; et al. Current approaches to avoid the culling of day-old male chicks in the layer industry, with special reference to spectroscopic methods. Poult. Sci. 2018, 97, 749-757. [CrossRef] [PubMed]

6. AAT (Agri Advanced Technologies), Press Release of 28th November 2017. Available online: https: / / www.agri-at.com/presse/15-pressemitteilungen-in-ovo/19-kuekentoeten-neue-vollautomatischeaanlag-zur-geschlechtsbestimmung-stellt-baldigen-ausstieg-in-aussicht (accessed on 9 November 2018).

7. Damme, K.; Ristic, M. Fattening performance, meat yield and economic aspects of meat and layer type hybrids. World's Poult. Sci. J. 2003, 59, 50-53. [CrossRef]

8. Koenig, M.; Hahn, G.; Damme, K.; Schmutz, M. Utilization of laying-type cockerels as "coquelets": Influence of genotype and diet characteristics on growth performance and carcass composition. Arch. Geflugelk. 2012, 76, 197-202. 
9. Upmann, M.; Lautenschläger, R. Fleisch vom Bruderhahn—Einsetzbar und zielführend für hochwertige Fleischerzeugnisse? Fachgespräch “Das Töten männlicher Eintagsküken vermeiden”, Düsseldorf, Germany, 21st March 2017. Available online: https:/ / www.hs-owl.de/ilt-nrw/fileadmin/user_upload/Vortrag_Prof. _Dr._Upmann_und_Prof._Dr._Lautenschlaeger.pdf (accessed on 9 November 2018).

10. Kaufmann, F.; Andersson, R. Eignung Männlicher Legehybriden zur Mast. Hochschule Osnabrück, Research Report 2011. Available online: https:// opus.hs-osnabrueck.de/files/10/Report_Kaufmann_Andersson.pdf (accessed on 9 November 2018).

11. Giersberg, M.F.; Spindler, B.; Kemper, N. Vergleichende Untersuchungen zum ZweinutzungshuhnVermeidung des Tötens männlicher Eintagsküken und mehr. In Tierschutz am Ende?-Zum Töten von Tieren, Proceedings of 22. Internationale Fachtagung zum Thema Tierschutz, München, Germany, 30 March-1 April 2017; Deutsche Veterinärmedizinische Gesellschaft (DVG): Gießen, Germany, 2017.

12. Hörning, B.; Häde, F. Zweinutzungshühner im Ökolandbau? Problematik, Pilotprojekte, Perspektiven. In Am Mut hängt der Erfolg—Rückblicke und Ausblicke auf die ökologische Landbewirtschaftung, Proceedings of 13. Wissenschaftstagung Ökologischer Landbau, Eberswalde, Germany, 17-20 March 2015; Häring, A.M., Hörning, B., Hoffmann-Bahnsen, R., Eds.; Verlag Dr. Köster: Berlin, Germany, 2015. Available online: http:/ / orgprints.org/27070/1/27070_hoerning.pdf (accessed on 9 November 2018).

13. AMI (Agrarmarkt Informations-Gesellschaft), Press Release of 5th July 2018. Available online: https:/ / www.ami-informiert.de/ami-maerkte/maerkte/ami-maerkte-eier-und-gefluegel/meldungen / single-ansicht/singleview / news/artikel/naechste-befragungsrunde-bei-bio-gefluegel-steht-an.html (accessed on 9 November 2018).

14. Andersson, R. (Hochschule Osnabrück, Osnabrück, Germany). Personal communication, 2018.

15. Giersberg, M.F. Assessment of animal based welfare and health indicators in male layer hybrids and dual-purpose chickens. Unpublished work, 2018.

16. DGS (Das Magazin für die Geflügelwirtschaft und Schweineproduktion), Survey—Wie steht der Ökolandbau zum Töten der männlichen Küken und gibt es eine favorisierte Alternative? DGS 2018, 18, 58.

(C) 2018 by the authors. Licensee MDPI, Basel, Switzerland. This article is an open access article distributed under the terms and conditions of the Creative Commons Attribution (CC BY) license (http:/ / creativecommons.org/licenses/by/4.0/). 